\title{
High-resolution Holocene climate and hydrological variability from two major Mediterranean deltas (Nile and Rhone)
}

\author{
Bassem Jalali, ${ }^{1,2}$ Marie-Alexandrine Sicre, ${ }^{2}$ Nejib Kallel, \\ Julien Azuara, ${ }^{3}$ Nathalie Combourieu-Nebout, ${ }^{3}$ \\ Maria-Angela Bassetti ${ }^{4}$ and Vincent Klein ${ }^{2}$
}

\begin{abstract}
High-resolution records of sea surface temperatures (SSTs) and terrestrial n-alkanes (TERR-alkanes) combined with pollen from the same sedimentary sequences were generated to assess variations in the Nile River discharge over the Holocene. These independent proxy records indicate a period of wetter conditions in the Nile watershed during the early-Holocene consistent with insolation-driven enhanced monsoon precipitation, known as the African Humid Period (AHP). The detection of a dry episode around $9200 \mathrm{yr}$ BP in the TERR-alkane and pollen time series suggests a temporary weakening of the monsoon intensity most probably triggered by extratropical cooling in the North Atlantic. An interval of C4 grass expansion between 8800 and $8400 \mathrm{yr}$ BP was also evidenced from the TERR-alkane distribution and confirmed by palynological data. SSTs of the coastal waters off the Nile delta reveal strong fluctuations in the early-Holocene followed by a slight warming and two pronounced cold intervals around 3500 yr BP and I500 yr BP. Comparison of these results with the same proxy data acquired from the Rhone River sediments (NW Mediterranean Sea) highlights an east-west contrast in the climate signals.
\end{abstract}

\section{Keywords}

African Humid Period, Holocene, Mediterranean, Nile delta, North Atlantic, Rhone River, sea surface temperatures

Received II June 2016; revised manuscript accepted I4 November 2016

\section{Introduction}

Deltas are repositories of both marine and terrestrial materials and as such they represent strategic sites to investigate the link between ocean conditions and environmental changes in adjacent land-masses. The geochemical composition of deltaic sediments provides a wealth of information that can be used to identify factors controlling river runoff variability on various time-scales. However, owing to the complexity of deltaic processes, a multiproxy approach is often needed for disentangling natural and human causes. The Nile and Rhone rivers form the two largest Mediterranean deltas. Their water and solid discharges result from different hydrological regime and characteristics of their catchment basin (nature of terrains, morphology, and vegetation cover) as well as land-use (deforestation, agricultural practices, dam construction, etc.) that have affected soil erosion over hundred to thousand years (Maselli and Trincardi, 2013). Deposits from these two Mediterranean deltas can inform on the climate history of river catchments, that is, mid-latitude environmental conditions of western Europe/NW Mediterranean (Rhone River) and tropical/subtropical climate dynamics (Nile River).

Prior to the construction of the Aswan High Dam in 1970, the Nile was the major supplier of freshwater $\left(85.1 \mathrm{~km}^{3} \mathrm{yr}^{-1}\right)$ and suspended solids $\left(120 \times 10^{6}\right.$ ton $\left.\mathrm{yr}^{-1}\right)$ to the eastern Mediterranean Sea (Williams et al., 2000). Its main tributaries are the Blue Nile and Atbara River in the Ethiopian Highlands and the White Nile that provide about $96.5 \%$ and $3.5 \%$ of the Nile sediment load, respectively (Williams et al., 2000). The Nile River runoff is strongly linked to the inter tropical convergence zone (ITCZ) seasonal variations governing the amount and seasonality of precipitation. The maximum Nile flow occurs in boreal summer when the ITCZ is at its northernmost position. During the early-Holocene, a period of enhanced monsoon precipitation in northeastern Africa, known as the African Humid Period (AHP), resulted in extreme runoff that significantly altered the thermohaline circulation of the Mediterranean leading to the formation of the so-called Mediterranean Sapropel S1 in the Eastern basin (Kallel et al., 1997a; Rohling, 1994; Rossignol-Strick et al., 1982). On decadal to centennial time-scale, smaller amplitude changes in river runoff because of

'GEOGLOB, Faculté des Sciences de Sfax, Université de Sfax, Tunisia 2LOCEAN Laboratory, Sorbonne Universités (UPMC, Univ Paris 06)-CNRS-IRD-MNHN, France

${ }^{3}$ Histoire naturelle de l'Homme Préhistorique (UMR 7I94 CNRS), Département de Préhistoire, Muséum national d'Histoire naturelle, Institut de Paléontologie humaine, France ${ }^{4}$ CEFREM-UMR5 I I 0 CNRS, Université de Perpignan, France

\section{Corresponding author:}

Bassem Jalali, GEOGLOB, Faculté des Sciences de Sfax, Université de Sfax, route de Soukra km 4-BP.802, 3038 Sfax, Tunisia.

Email: bassemjalali@yahoo.fr 


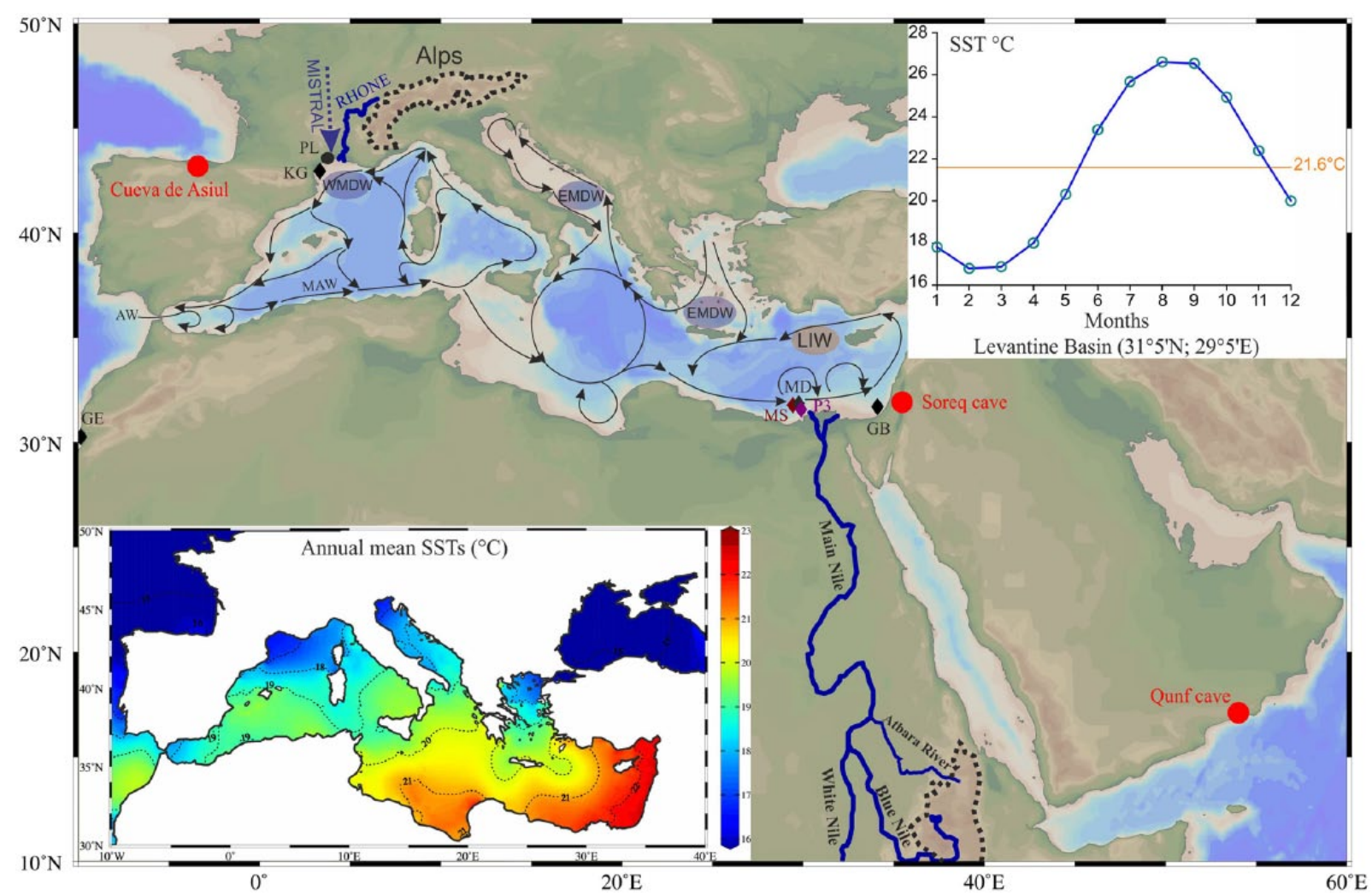

Figure I. Map of the Mediterranean region showing the location of sites referred to in the text. Mediterranean annual mean SSTs $\left({ }^{\circ} \mathrm{C}\right.$; 1955-20I2) are shown in the bottom-left insert. Mean monthly SSTs in the SE Mediterranean (horizontal lines indicate the annual mean SSTs, ca. $21.6^{\circ} \mathrm{C}$ ) from World Ocean Atlas Database (NOAA/NODCWOAI3 $\left(0.25^{\circ}\right.$ grid)) are shown in the upper right insert. Mediterranean surface currents and Mistral wind are shown by solid and dotted arrows, respectively. Diamonds and red circles indicate the marine and speleothem sites, respectively (see text). The location of Palavasian lagoon (PL) in southern France is shown by black circle. AW:Atlantic water; MAW: modified Atlantic water;WMDW: western Mediterranean deep water; EMDW: eastern Mediterranean deep water; LIW: Levantine intermediate water; KG: KSGC-3I_Gol-HoIB; GE: GeoB 6007-2; MS: MS27PT; MD: MD04-2726; P3: P362/2-33; GB: GeoB 7702-3.

natural variability and the artificial regulation of river streams can impact on local temperature and salinity and modulate convection, but variability at these time-scales has been little explored.

Subject to different climatological conditions, the Rhone River is the main water stream discharging into the western Mediterranean Sea with an annual freshwater discharge of $58.5 \mathrm{~km}^{3}$ $\mathrm{yr}^{-1}$ and a sediment supply of $31 \times 10^{6}$ ton $\mathrm{yr}^{-1}$ (Ludwig et al., 2009). Its hydrological regime is tightly linked to the amount of rainfall as well as glaciers and snow melting (Ludwig et al., 2009). Heavy precipitations triggered by southerly maritime winds are frequent in autumn (September and October) leading to devastating floods in southern France. Mid-latitude Atlantic storms occurring along the year also contribute to the Mediterranean annual precipitation. The delivery and accumulation of continental material in the Rhone delta are also strongly dependent on soil erosion, vegetation cover, and human activities (Fanget et al., 2014; Provansal et al., 2003). Highest sediment accumulation occurs close to the river mouth while finer particles are transported with the alongshore river plume driven by costal currents to settle on the mid-shelf of the Gulf of Lion (GoL) forming a 'mud belt' or 'subaqeuous delta' (Cattaneo and Steel, 2003; Nittrouer et al., 1986; Pratson et al., 2007) where accumulation rate can reach $\sim 1 \mathrm{~m} / 1000$ years.

Recent syntheses on the Mediterranean Holocene climate based primarily on continental archives have shown an east-west contrast of the Mediterranean hydroclimate (Magny et al., 2013; Roberts et al., 2008, 2011). Recently, Joannin et al. (2014) suggested a more complex pattern involving northeast/southwest versus southeast/south central poles underpinning gaps in our knowledge. Here, we present a new multi-proxy study that combines sea surface temperatures (SSTs) and land-derived indicators of paleoenvironmental conditions, that is, wax n-alkane biomarkers (thereafter named terrestrial n-alkane (TERR-alkanes)), Ti:Ca ratios, and pollen data preserved in the Nile delta sediments to investigate further this issue. We compare this dataset with the same proxy data from the Rhone River mud belt sediments (NW Mediterranean; Bassetti et al., 2016; Jalali et al., 2016) and speleothem isotope records to evaluate regional pattern and discuss possible mechanisms to explain trans-Mediterranean contrasts.

\section{Material and methods}

\section{Sediment cores' description and age models}

Two cores MD04-2726 (31.85 ${ }^{\circ} \mathrm{N}, 29.78^{\circ} \mathrm{E} ; 1058 \mathrm{~m}$ water depth) and MS27PT $\left(31.78^{\circ} \mathrm{N}, 29.45^{\circ} \mathrm{E} ; 1389 \mathrm{~m}\right.$ water depth) were recovered from the Rosetta upper slope during the VANIL and MedifluxMIMES cruises, on the $R / V$ Pelagia, respectively (MD and MS in Figure 1). Both cores are located less than $90 \mathrm{~km}$ from the Nile River mouth but have different sedimentation rates because of their location relative to the Rosetta channel $(\sim 163$ $\mathrm{cm} / 1000$ years for MD04-2726 versus $76 \mathrm{~cm} / 1000$ years for MS27PT). The age model of core MD04-2726 is based on 12 AMS ${ }^{14} \mathrm{C}$ dates while that of core MS27PT uses 17 AMS ${ }^{14} \mathrm{C}$ dates. Details on the establishment of the age models can be found in Revel et al. (2015). Uncertainties were estimated using the Bayesian approach of OxCal 4.2 software. The mean uncertainty along the MD04-2726 core is $\sim 300$ years while for MS27PT it does not exceed 133 years. The proxy records generated from MD04-2726 core span from 7600 to $473 \mathrm{yr}$ BP (age of the core-top) at a mean temporal resolution of 57 years. The MS27PT covers the early-Holocene (10,000-6800 yr BP) and thus encompasses the AHP. Owing to its higher sedimentation 
rates, a mean temporal resolution reached 18 years. All together, the two cores provide a complete climate description of the Holocene, except for the last 500 years.

The 7-m-long KSGC-31 gravity core and 20-cm-long GolHo1B multi-core were retrieved from virtually the same location in the GoL $\left(43^{\circ} \mathrm{N}, 3.29^{\circ} \mathrm{E} ; 60 \mathrm{~m}\right.$ water depth; $\mathrm{KG}$ in Figure 1) and spliced to produce a full reconstruction of Holocene SSTs including the post-industrial Era, in this particular area of deep water formation. The age model of KSGC-31_Gol-Ho1B record is based on $21 \mathrm{AMS}{ }^{14} \mathrm{C}$ dates measured on bivalve shells. ${ }^{210} \mathrm{~Pb}$ was also measured in the upper portion of KSGC-31 gravity core and along the Gol-Ho1B multi-core. Based on AMS ${ }^{14} \mathrm{C}$ and ${ }^{210} \mathrm{~Pb}$ chronologies, we could establish that the gravity core KSGC-31 ranges from 10,000 $( \pm 137) \mathrm{yr} \mathrm{BP}$ to $\mathrm{AD} 1971( \pm 1.4)$, and that the multi-core Gol-Ho1B spans from AD $1960( \pm 5.6)$ to 2013. Details on the age model can be found in Sicre et al. (2016) and Jalali et al. (2016). The KSGC-31_Gol-Ho1B proxy records have a mean temporal resolution of $\sim 15$ years that is thus comparable to the early-Holocene Nile River record.

The PB06 piston core $(7.7 \mathrm{~m}$ long) used for comparison was recovered from the Pierre Blanche lagoon in the Palavasian lagoonal complex, Southern France (PL in Figure 1). The pollen record generated over the past 4600 years and published by Azuara et al. (2015) has been extended here back to $6500 \mathrm{yr}$ BP. The PB06 age model is based on ${ }^{210} \mathrm{~Pb}$ and ${ }^{137} \mathrm{Cs}$ activity measured in the upper $35 \mathrm{~cm}$ and $19 \mathrm{AMS}{ }^{14} \mathrm{C}$ dates (Sabatier et al., 2012). The mean temporal resolution of $\sim 56$ years is lower than the terrestrial biomarker data of the GoL core (KSGC-31 GolHo1B). We applied binning to all signals to reduce the effect of errors in the proxy reconstructions. The choice of a 200 -year was made to reflect age uncertainties associated with $\mathrm{AMS}{ }^{14} \mathrm{C}$ dating (McGregor et al., 2015). All cores have been collected and analyzed with the international MISTRALS/PaleoMeX program.

\section{Biomarker analyses}

All cores were sampled continuously at a sampling step of $1 \mathrm{~cm}$. Lipids were extracted from a few grams of freeze-dried sediments. A detailed description of the methodology used to process the samples can be found in Ternois et al. (2000). Alkenone-SSTs were calculated from the global calibration of Conte et al. (2006), that is, $\mathrm{T}\left({ }^{\circ} \mathrm{C}\right)=-0.957+54.293\left(\mathrm{Uk}^{\prime}{ }_{37}\right)-52.894\left(\mathrm{Uk}^{\prime}{ }_{37}\right)^{2}+$ $28.321\left(\mathrm{Uk}^{\prime}{ }_{37}\right)^{3}$. For the n-alkanes, only the high-molecular-weight homologs with an odd carbon number, that is, C27, C29, C31, and C33, were quantified to derive terrestrial inputs delivered by both rivers $(\Sigma \mathrm{C} 27+\mathrm{C} 29+\mathrm{C} 31+\mathrm{C} 33$, thereafter named TERRalkanes). TERR-alkanes are constituents of epicuticular wax of leaves synthesized by higher plants. Under water deficit, plants adapt to moisture conditions by producing longer chain wax n-alkanes to minimize water loss by evapo-transpiration (Gagosian and Peltzer, 1986). To derive information on changing moisture conditions during the Holocene, we calculated the n-alkane average chain length $(\mathrm{ACL})$ between $\mathrm{C}_{27}$ and $\mathrm{C}_{33}\left(\mathrm{ACL}_{27-33}=\right.$ $\Sigma\left\{\left(27 \times\left[\mathrm{C}_{27}\right]\right)+\cdots+\left(33 \times\left[\mathrm{C}_{33}\right]\right)\right\} / \quad \Sigma\left(\left[\mathrm{C}_{27}\right]+\cdots+\left[\mathrm{C}_{33}\right]\right)$. This index has been developed and successfully applied to TERRalkanes in aerosols to assess source regions (Gagosian and Peltzer, 1986; Sicre and Peltzer, 2004).

\section{Pollen methodology}

Pollens were determined as a complementary information source of vegetation changes. The pollen extraction procedure used is based on the standard method modified from Faegri and Iversen (1989) (for details, see Azuara et al., 2015; Combourieu-Nebout et al., 1999). Pollen concentration estimates were calculated using tablets containing a known amount of Lycopodium spores (Stockmarr, 1971). Three pollen curves were produced based on 25 samples from the MS27PT core to evaluate vegetation changes associated with the ITCZ fluctuations during the AHP. The concentration of Pediastrum (Matthiessen et al., 2000) was used to track the Nile River discharge and pollen tropical taxa (mainly Podocarpus) those of the Blue Nile. Pediastrum is a freshwater algae living in colonies in rivers and deltas. Its occurrence in the Nile delta sediments is indicative of flood regime. Podocarpus is a tree living in the Ethiopian highlands today and has never been recorded in the Nile valley (McGlynn et al., 2013; Rucina et al., 2009). It is thus informative of the long-distance transport of the material from this remote region by the Nile River waters. This pollen is present in significant abundance in the first half of Holocene as expected from the moisture conditions in the tropical band and subsequent inputs because of high Blue Nile discharge. The changes in aridity were evaluated from pollen percentages of steppe taxa.

In the GoL, TERR-alkanes and $\mathrm{ACL}_{27-33}$ reconstructions from the KSGC-31 Gol-Ho1B core are discussed together with the pollen data acquired from the nearby Palavasian lagoon sediments. This lagoon is fed by small river streams (Lez, Mosson, Coulazou) with an overall catchment basin extending less than 50 $\mathrm{km}$ hinterland in coastal lowland hills of Southern France, as opposed to that of the Rhone River that has a much larger northsouth extension. We used the relative abundances of Fagus sylvatica and deciduous Quercus in these lagoon sediments to identify wet/dry time intervals (Azuara et al., 2015). In southern France mountains, Fagus sylvatica is present at the limit of its geographical range. Its distribution is particularly sensitive to climate fluctuations and notably moisture availability (Delhon and Thiébault, 2005; Quezel, 1979). On the other hand, Quercus pubescens, the most abundant deciduous oak nowadays in southern France, is more tolerant to seasonal aridity. Past variations in these two taxa when Fagus retreated and deciduous Quercus expanded underline arid conditions. The Fagus:Quercus ratio record was thus used here to detect alternation of dry/wet periods in the Palavas lagoon sequence.

\section{Results and discussion}

\section{Alkenone SST signal}

As can be seen from the monthly instrumental SSTs off the Nile delta obtained from the World Ocean Atlas Database 2013 at our core site from 1955 to 2012 (NOAA/NODC WOA13; Locarnini et al., 2013; Figure 1, upper right insert), values range from $17^{\circ} \mathrm{C}$ in winter to above $26^{\circ} \mathrm{C}$ in summer, resulting in an annual mean of $21.6^{\circ} \mathrm{C}$. According to flux data from deep sediment traps deployed in the Bannock Basin (central eastern Mediterranean), maximum production of Emiliania huxleyi today takes place in spring, mainly in March-April-May (Ziveri et al., 2000). Assuming that alkenone production seasonality is the same at our core site, we calculated MAM average value of $18.4^{\circ} \mathrm{C}$. This estimate is $3^{\circ} \mathrm{C}$ cooler than the MD04-2726 core-top value of $21.2 \pm 0.2^{\circ} \mathrm{C}$, which is instead closer to the annual mean today, $21.6^{\circ} \mathrm{C}$. Although alkenone production and SSTs may have been different 500 years ago (age of the MD04-2726 core-top), we can reasonably conclude based on the available information that alkenonederived SSTs reflect annual mean rather than spring temperatures. A similar finding has been reported for the alkenone SST signal in the GoL (NW Mediterranean), but the annual mean in this area is among the coldest of the Mediterranean Sea (i.e. $17^{\circ} \mathrm{C}$, Figure 1, lower left insert) because of the strong surface water cooling induced by Mistral winds blowing throughout the year (Sicre et al., 2016). These two locations thus represent the most extreme SST values of the whole Mediterranean basin.

Figure 2b shows the 200-year binned SST reconstruction from 10,000 to $500 \mathrm{yr}$ BP off the Nile River obtained by the MD04-2726 and MS27PT cores. The MS27PT core documents 


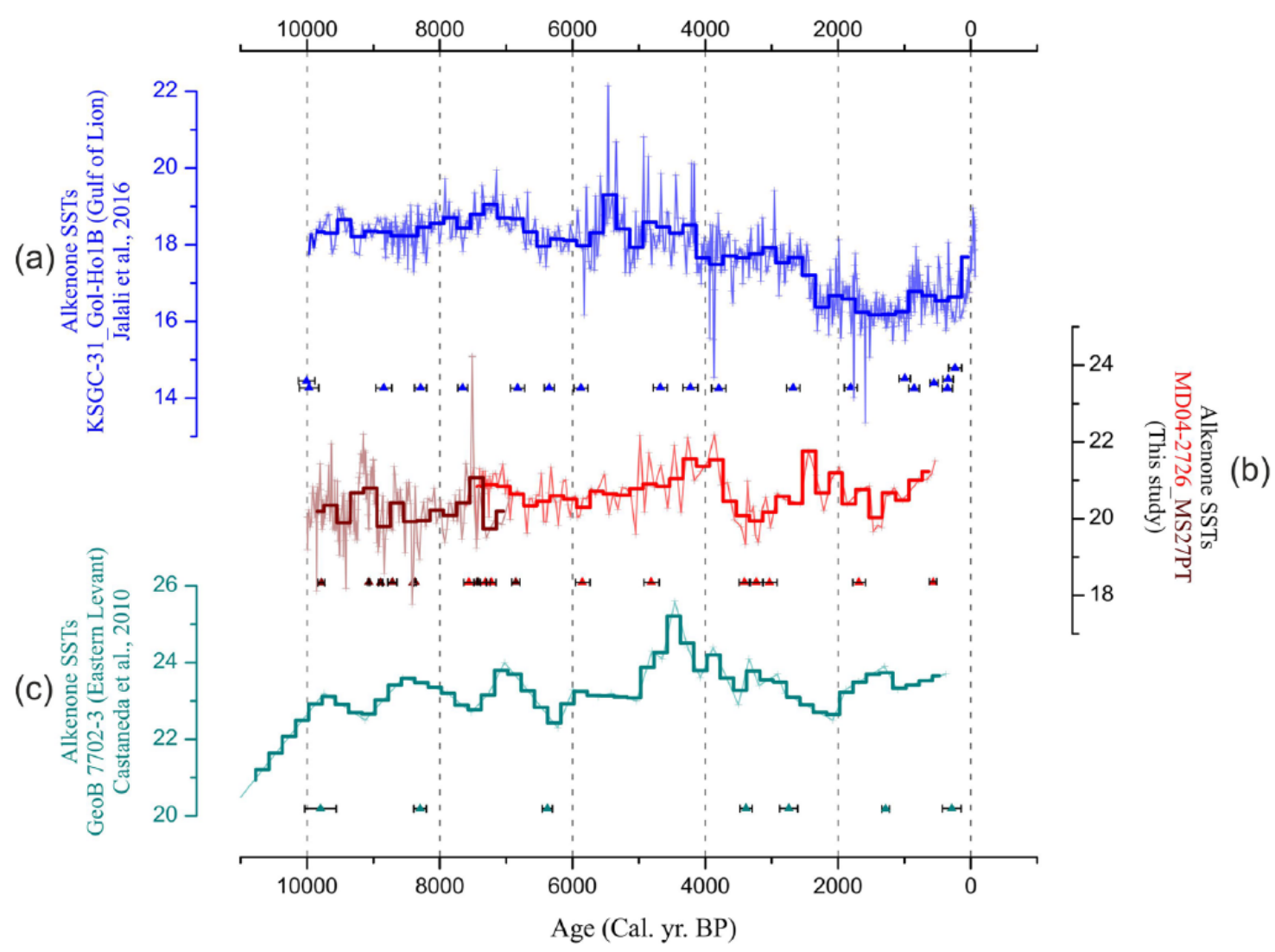

Figure 2. Holocene alkenone SST reconstructions from (a) the KSGC-3I_Gol-HolB core (GoL, from Jalali et al., 20I6), (b) the MD04-2726 and MS27PT cores (Nile delta, this study), and (c) the GeoB 7702-3 core (SE Levantine basin, from Castañeda et al., 2010). A 200-year binning was applied to all records to reduce the effect of error in the proxy reconstructions. Triangles for each time series indicate the AMS I4C tie points used to establish age models.

the first 3000 years of Holocene while the MD04-2726 extents this record to $500 \mathrm{yr}$ BP. The MS27PT signal, roughly corresponding to the AHP, depicts strong SST fluctuations around a value of $\sim 20.3^{\circ} \mathrm{C}$ that is comparable to what has been found in the nearby core P362/2-33 (P3 in Figure 1) for the same period (see Fig. S1b in Blanchet et al., 2014). Note that the higher temporal resolution of the MS27PT signal (20years) as compared with MD04-2726 (ca. 60 years) may, in part, account for higher frequency oscillations in the first half of the Holocene. From 7000 to $4000 \mathrm{yr}$ BP, SSTs increase slightly till an abrupt decline at $\sim 3500 \mathrm{yr}$ BP. After a warm phase during the Roman Period, SSTs decrease again at $\sim 1500 \mathrm{yr} B P$, that is, the Dark Ages Cold Period (DACP). The final rise seen toward the end of the core $\left(\sim 1^{\circ} \mathrm{C}\right)$ is likely featuring the onset of the Medieval Climate Anomaly (MCA). Comparison with the SST signal derived from alkenones of the nearby core GeoB 7702-3 located further east (GB in Figure 1) shows some resemblance with our record (Figure $2 \mathrm{~b}$ and c; Castañeda et al., 2010). The general warming trend with superimposed centennial-scale fluctuations during the first half of the Holocene and the well-expressed mid-Holocene warmth between 5000 and $4000 \mathrm{yr}$ BP followed by a cooling are common features of the two cores though slightly shifted in time. This is in contrast to the GoL record (Figure 2a) showing warm values $\sim 18 \pm 0.4^{\circ} \mathrm{C}$ during the early-Holocene followed by a long-term cooling starting $\sim 7000 \mathrm{yr}$ BP culminating at the DACP and a final post-industrial warming starting around AD 1850. Several centennial-scale cold relapses superimposed to these trends that seem contemporary to cold intervals in the North Atlantic were also identified (Jalali et al., 2016). The Nile and Rhone delta records thus display broadly opposite trends in temperature as already pointed out by Jalali et al. (2016) based on a basin-wide compilation of Holocene SST records. Our findings seem to support the idea of an east-west contrast seen in hydroclimate proxies from continental archives across the Mediterranean region (Roberts et al., 2012).

\section{Land-derived inputs from the Nile delta}

Early- to mid-Holocene-AHP. TERR-alkane biomarkers produced by higher plants were used to assess the variations in land-derived material delivered by the Nile River to the Rosetta channel. Both their concentrations and molecular distributions contain valuable paleoenvironmental information to get some insight into the changes in precipitation over the Nile catchment basin. As can be seen from the TERR-alkane concentration downcore profile (Figure $3 \mathrm{~b}$ ), the beginning of the Holocene is characterized by high and strongly fluctuating values peaking around $9200 \mathrm{yr}$ BP followed by an abrupt drop inserted in a broad decrease which lasted till $6000 \mathrm{yr}$ BP. Note that the overlapping period of the two cores shows slightly different TERR-alkane levels that probably reflect the spatial heterogeneity of sediment input and deposition in the delta. This hypothesis is supported by the $\log (\mathrm{Ti}: \mathrm{Ca})$ values measured over the entire two cores (Revel et al., 2015) that show different values and shape (Figure 3d). Because Ti in the Nile delta sediments originates from terrigenous-siliciclastic material while $\mathrm{Ca}$ is primarily from biogenic carbonates produced in coastal waters, the $\log (\mathrm{Ti}: \mathrm{Ca})$ ratio has been used to assess past Nile River discharge in relation to rainfall (Revel et al., 2015). High and variable early-Holocene $\log (\mathrm{Ti}: \mathrm{Ca})$ values have been related to Nile River flooding triggered by insolation-driven monsoon precipitation (Figure 3a). The $\log (\mathrm{Ti}: \mathrm{Ca}$ ) ratios start declining at $\sim 8400 \mathrm{yr}$ $\mathrm{BP}$ in the MS27PT core and only around $\sim 7700 \mathrm{yr}$ BP in the MD04-2726 core. The latter value agrees with the results of Marriner et al. (2012) obtained from the compilation of more than a 


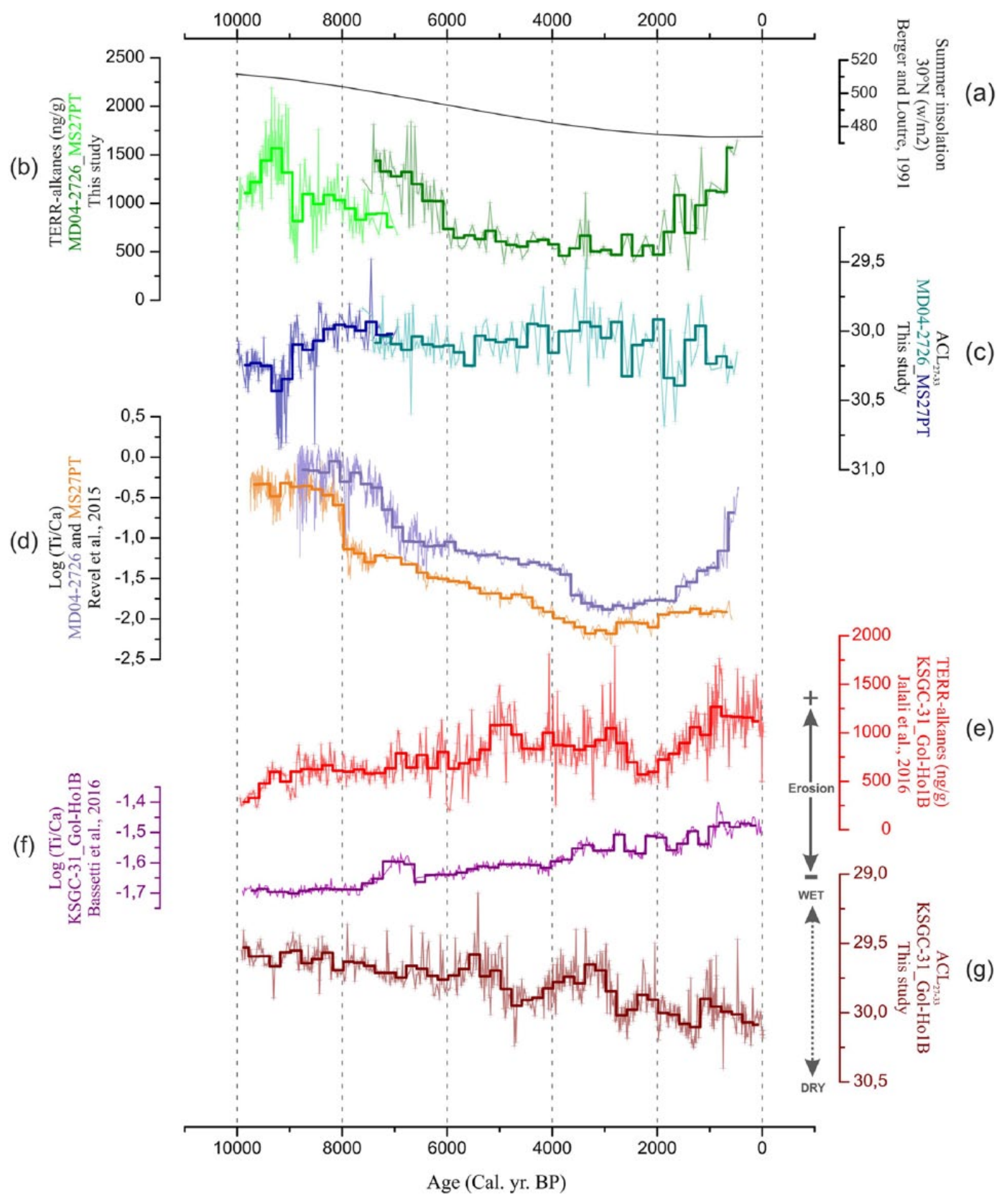

Figure 3. Reconstruction over the past 10,000 years of (a) summer insolation at $30^{\circ} \mathrm{N}$ (Berger and Loutre, I99I), (b) TERR-alkane abundances in the MD04-2726 and MS27PT cores, (c) changes in ACL $_{27-33}$ in the MD04-2726 and MS27PT cores (inversed vertical axis), (d) log Ti:Ca ratios in the MD04-2726 and MS27PT cores (from Revel et al., 20I5), (e) TERR-alkane abundances at the KSGC-3I_Gol-HoIB site (from Jalali et al., 20I6), (f) log Ti:Ca ratios at the KSGC-3I_Gol-HolB site (from Bassetti et al., 20I6), and (g) changes in ACL $27-33$ at KSGC-3I_GolHolB core (inversed vertical axis).A 200 -year binning (darkened lines) was applied to all records to reduce the effect of error in the proxy reconstructions.

hundred cores from the Nile delta $(\sim 7700 \mathrm{yr} \mathrm{BP})$. The $\sim 700$ years lead of this transition from high to $\operatorname{low} \log (\mathrm{Ti}: \mathrm{Ca})$ in the MS27PT is beyond age model uncertainties that are on the order of a century. The observed difference between the two records can be explained by a diachronic contribution of the various tributaries to the Nile River discharge and heterogeneity of sedimentation in the Rosetta canyon, although we cannot totally rule out a possible artifact from an abrupt change in sedimentation. Additional information from the strontium isotope of the Levantine basin sediments indicates that the Nile discharge decrease between 8500 and 7000 yr BP results from a lower contribution of the Blue Nile and Atbara River (Blanchet et al., 2015). This reduction in the Blue Nile flow would be caused by lower rainfall as the ITCZ starts migrating south toward the end of the AHP. Besides monsoon rainfall, the Mediterranean source would have also been important in the reduction in the Nile discharge (Blanchet et al., 2015).
Vegetation types in the tropical and subtropical Africa can be broadly distinguished by the ACL. This index expresses the metabolic response of vegetation to moisture availability. Because $\mathrm{C}_{35}$ and $\mathrm{C}_{25}$ were barely detectable in the Nile delta sediments, the $\mathrm{ACL}$ index was calculated between $\mathrm{C}_{27}$ and $\mathrm{C}_{33}\left(\mathrm{ACL}_{27-33}\right.$; Figure $3 c)$. For comparison with our reconstructions, $\mathrm{ACL}_{27-33}$ was also calculated from the $n$-alkane distributions measured in various source materials provided by Vogts et al. (2009), which includes several savanna and rain forest species (Figure 4b). Pollen data were also determined in a limited number of horizons of the earlyHolocene (MS27PT core) for complementary information on the vegetation (Figure $4 \mathrm{e}-\mathrm{g}$ ).

The very beginning of the Holocene shows slowly increasing $\mathrm{ACL}_{27-33}$ values lying between those of savanna shrubs (30.2) and savanna herbs (30.6) maximizing at $\sim 9200 \mathrm{yr} B P$ at the time of TERR-alkane peaking suggesting the expansion of a vegetation 


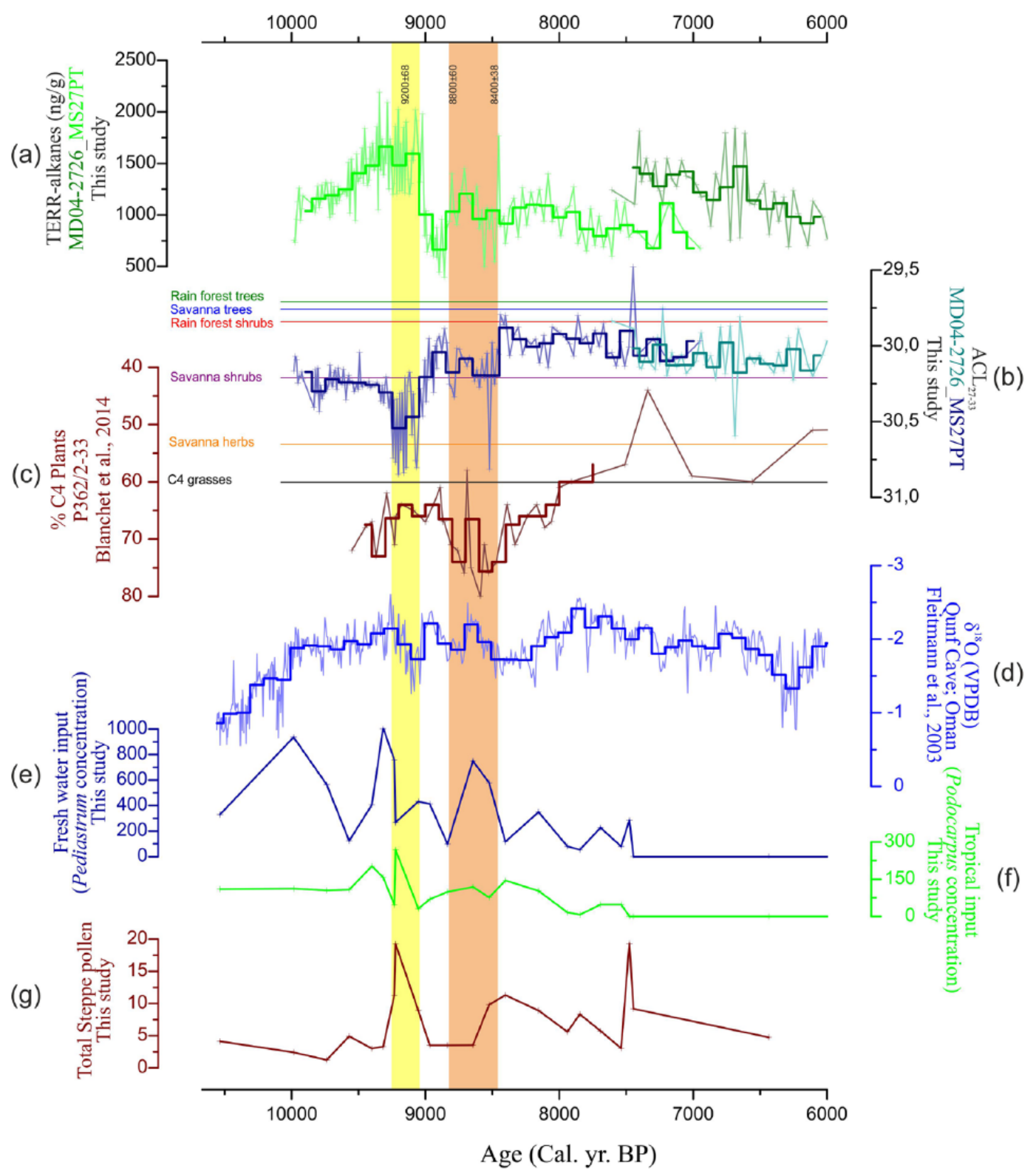

Figure 4. Reconstruction of paleoenvironmental conditions in the Nile River watershed between 10,000 and 6000 yr BP. (a) TERR-alkane abundances at MS27PT and MD04-2726 core sites. (b) ACL $_{27-33}$ at MS27PT and MD04-2726 core sites. Horizontal colored lines indicate mean $\mathrm{ACL}_{27-33}$ values for vegetation types in tropical and subtropical Africa from Vogts et al. (2009). (c) Percent of C4 plants in P362/2-33 core (from Blanchet et al., 2014). (d) $\delta^{18} \mathrm{O}$ values in the Qunf Cave speleothem (from Fleitmann et al., 2007). (e) Pediastrum concentration (in grains $\mathrm{cm}^{-3}$ of sediment) in the MS27PT core. (f) Concentration of tropical pollen (mainly Podocarpus; in grains $\mathrm{cm}^{-3}$ of sediment) in the MS27PT core. (g) Total steppe pollen percentages in the MS27PT core. The vertical yellow and orange bars highlight two outstanding time intervals discussed in the text. From (a) to (d), a 100-year binning (darkened lines) was applied.

adapted to drier conditions (Figure $4 \mathrm{a}$ and $\mathrm{b}$ ). The occurrence of this arid episode is supported by higher total steppe pollen and lower Podocarpus pollen originating from the Ethiopian tropical mountains today (Figure $4 \mathrm{f}$ and $\mathrm{g}$ ). Then, $\mathrm{ACL}_{27-33}$ indicates a rapid return to wetter conditions (lower $\mathrm{ACL}_{27-33}$ ) and concomitant decrease in TERR-alkanes till about 8800 yr BP. From 8800 to $8400 \mathrm{yr} \mathrm{BP}$, both TERR-alkanes and $\mathrm{ACL}_{27-33}$ show slightly higher values, although not as high as during the 9200 -year event (Figure $4 \mathrm{a}$ and $\mathrm{b}$ ). This four-century-long period coincides with enhance abundances of $\mathrm{C} 4$ grasses $\left(\mathrm{ACL}_{27-33} \sim 30.9\right)$ observed by Blanchet et al. (2014) (Figure 4c) ending by a sharp decrease to among the lowest $\mathrm{ACL}_{27-33}$ values of the record (29.8). These results suggest that enhanced precipitation allowed vegetation to expand in the Green Sahara till about 8400 yr BP. High and variable concentrations of the freshwater algae Pediastrum (Figure $4 \mathrm{e})$ combined with high $\log (\mathrm{Ti}: \mathrm{Ca})$ values are consistent with a high Nile discharge (Blanchet et al., 2013, 2015; Costa et al.,
2014; Marshall et al., 2011). Interestingly, Pediastrum show low values during the $\sim 9200 \mathrm{yr}$ BP but high ones between 8800 and $8400 \mathrm{yr}$ BP, a result that reinforces the idea of a drier climate at $9200 \mathrm{yr} \mathrm{BP}$ as opposed to the subsequent wet interval (8800-8400 yr BP). After 8400 yr BP, TERR-alkanes progressively decrease in parallel to increasing $\mathrm{ACL}_{27-33}$ suggesting a progressive retreat of savanna vegetation cover and decline in the Nile flow till about $6000-5500$ yr BP.

As earlier outlined, the dry spell $\sim 9200 \mathrm{yr}$ BP for the first time evidenced in the Nile sediment is an outstanding feature of the AHP. The biomarker and pollen data emphasize a larger representation of non-arboreal pollen during this particular interval, especially the steppe components (Figure 4g) that are clearly indicative of enhanced dryness in the Blue Nile catchment basin. This event coincides with a cold interval in Greenland ice cores (Vinther et al., 2006) as well as higher values of oxygen isotope of the Qunf Cave speleothem located in southern Oman (Figure 4d) and 
at several other sites of the Northern Hemisphere, which has been attributed to the weakening of the Indian and Asian monsoons (Fleitmann et al., 2007, 2008). Our results thus evidence that this extratropical North Atlantic cooling substantially affected the vegetation of the Nile catchment basin. The second notable interval of the AHP (8800-8400 yr BP) reveals the expansion of savanna shrubs to the Sahara region associated with the maximum northward position of the African Rain Belt and the gradual establishment of the so-called Green Sahara. According to Vijverberg et al. (2009), the contribution of the dry mountain forest in the Ethiopian highlands characterized by a mixture of $\mathrm{C} 3$ and $\mathrm{C} 4$ plants is also likely.

Mid- to late-Holocene. The AHP is followed by a period of low TERR-alkanes from 6000 to $2000 \mathrm{yr}$ BP and a steep increase during the Common Era that is also seen in the $\log (\mathrm{Ti}: \mathrm{Ca})$ record of the MD04-2726 core but weakly expressed in the MS27PT record (Figure $3 \mathrm{~b}$ and $\mathrm{d}$ ). $\mathrm{ACL}_{27-33}$ values are characterized by large centennial-scale variations evolving from rain forest shrubs to savanna shrubs when reaching the DACP (Figure 3c). The succession of intervals both high $\mathrm{ACL}_{27-33}$ and TERR-alkanes and low $\mathrm{ACL}_{27-33}$ and TERR-alkanes reveals an alternation of wet and dry spells. Over the past 2000 years, our data suggest drier conditions and the deterioration of the vegetation cover in the Nile drainage basin, with strong centennial fluctuations. Possible causes for this variability are discussed later.

\section{Northwest-southeast climate contrast}

The same proxy reconstructions as for the Nile delta were also generated at high resolution from the Rhone mud belt sediments deposited on the mid-shelf of the GoL at the KSGC-31_GolHo1B site (Bassetti et al., 2016; Jalali et al., 2016). In this section, we make a systematic comparison of the Nile and GoL biomarker data with other high-resolution proxy climate records in these two geographical end-members of the Mediterranean region.

Holocene trends. The early-Holocene SST signal from the NW Mediterranean GoL sediments appeared stable and generally warmer than today till about $7000 \mathrm{yr}$ BP when they start cooling (Figure 2a) in agreement with the compilation of over 50 marine cores of Marcott et al. (2013) showing an extratropical cooling presumably driven by summer insolation. The slight SST warming found off the Nile delta (Figure 2b) and at other Eastern Mediterranean sites (Jalali et al., 2016) till about $5000 \mathrm{yr}$ BP is also consistent with the findings of Marcott et al. (2013) in tropical regions $\left(30^{\circ} \mathrm{S}-30^{\circ} \mathrm{N}\right)$. Superimposed to these cooling/warming trends, our two SST records show strong centennial-scale fluctuations that suggest sub-millennial-scale climate forcing other than insolation.

Land-derived indicators have shown Nile flooding in the first half of the Holocene except around $9200 \mathrm{yr}$ BP when monsoon weakened in response to extratropics forcing. This is in contrast to the steady increase in $\log (\mathrm{Ti}: \mathrm{Ca})$ ratios in the GoL from earlyHolocene to present that suggests an increasing erosion of soil material in the Rhone River watershed (Figure 3f; Bassetti et al., 2016). TERR-alkanes show a similar tendency but stronger fluctuations in the mid- to late-Holocene and a drastic drop around 2500 yr BP (Figure 3e). Together with the parallel $\mathrm{ACL}_{27-33}$ increase along the sequence (Figure 3g), these data suggest the progressive expansion of drier climate vegetation type over the course of the Holocene. According to Jalut et al. (1997), temperate deciduous forest dominated in southern France during the first half of the Holocene because of favorable oceanic climate characterized by regular precipitation along the year and wet summers. Because deciduous trees produce high amounts of $\mathrm{C}_{29}$ alkanes (Schwark et al., 2002), they are likely to have contributed to the low $\mathrm{ACL}_{27-33}$ in the first half of the Holocene. Wet conditions in the western Mediterranean Sea have also been inferred from lower sea surface salinity between $\sim 9500$ and 5500-5000 yr BP (Kallel et al., 1997b, 2004; Melki et al., 2009). From 5500 yr BP onward, palynological data indicate that the vegetation cover in southern France broadly shifted from deciduous to evergreen trees and shrubs dominating vegetation as the Mediterranean climate were established (Azuara et al., 2015; Jalut et al., 2000, 2009). This change in vegetation is coherent with increasing $\mathrm{ACL}_{27-33}$. However, this shift in vegetation type that tolerates dry summers results in land exposure and subsequent soil erosion that would account for rising $\log (\mathrm{Ti}: \mathrm{Ca}$ ) ratios (Jalut et al., 2000). Increasing dryness and progressive deterioration of the vegetation cover are supported by other paleoenvironmental studies in the western Mediterranean (Jiménez-Espejo et al., 2014; JiménezMoreno et al., 2015; Pérez-Obiol et al., 2011; Roberts et al., 2011; Zazo et al., 2005). To summarize, the GoL data indicate prevailing oceanic climate during the early-Holocene in the western Mediterranean/southern Europe while monsoon precipitation dominated in the northeastern Africa. Around the mid-Holocene, records in the two regions indicate a gradual drying that is primarily driven by insolation and the southward migration of the ITCZ. Superimposed centennial-scale variations suggest other climate teleconnections that are discussed in the next section.

Sub-millennial to centennial-scale variability. Both in the western and eastern Mediterranean, SSTs and terrestrial proxy reconstructions show strong centennial-scale variability from the mid-Holocene onward, when the ITCZ was more southerly. In the GoL, we see a clear alternation of wet and dry phases over the overall drying trend, as for instance the following low $\mathrm{ACL}_{27-33}$ and TERRalkanes more humid intervals: 5800-5000, 4200-3000, 2400-1800, and 1200-900 yr BP (Figure 5b). Pollen data from the Palavasian lagoon and in particular the high Fagus/Quercus ratio value confirm the occurrence of these wet spells, which broadly coincide with warm SSTs (Figure 5a). This ratio together with charcoal data recovered in the nearby coastal lowlands clearly demonstrates that beech forest were abundant at lower elevations between 6000 and $2000 \mathrm{yr}$ BP than nowadays $(<1000$ $\mathrm{m})$ in the Languedoc region and that both species competed in low elevation areas of the Mediterranean region (Azuara et al., 2015). Because Fagus/Quercus ratio reflects inputs from the local vegetation supplied by three river streams, we can conclude from the similarity with TERR-alkanes and $\mathrm{ACL}_{27-33}$ signals that over this time interval the material reaching the GoL primarily originates from Mediterranean shrublands from the lower Rhone River catchment basin tributaries as hypothesized by Jalali et al. (2016).

The $\delta^{18} \mathrm{O}$ record of the Asiul Cave stalagmite in northern Spain further underlines increased precipitation during these time intervals (Smith et al., 2016; Figure 5d). Other evidences come from major lake-level highstands in the Apennines and the northwestern Alps in southern Europe (Accesa and Cerin Lakes; Magny et al., 2007, 2011). Humid conditions today in the Mediterranean region are linked to negative NAO state. More zonal and southerly westerly winds are indeed responsible for Mediterranean winter precipitations mainly in October-March (Trigo and Davies, 2000). The extremely low TERR-alkanes and $\mathrm{ACL}_{27-33}$ around $2500 \mathrm{yr} \mathrm{BP}$ in the GoL coincide with the weakest NAO years reconstructed by Olsen et al. (2012) and the southernmost position of the ITCZ according to the \% Ti in Cariaco Basin (Haug et al., 2001). Between these well-marked wet episodes, interspersed dry spells of high $\mathrm{ACL}_{27-33}$ in the GoL sediments and low abundances of Fagus pollen are also clearly distinct in the Palavasian lagoon sediments (shaded area in Figure 5). They broadly correspond to enhanced dryness seen in the northern Spain stalagmite oxygen isotope record (Figure 5d, Smith et al., 2016) and cold SSTs in the GoL (Figure 5a and d). Similar concomitant dry 


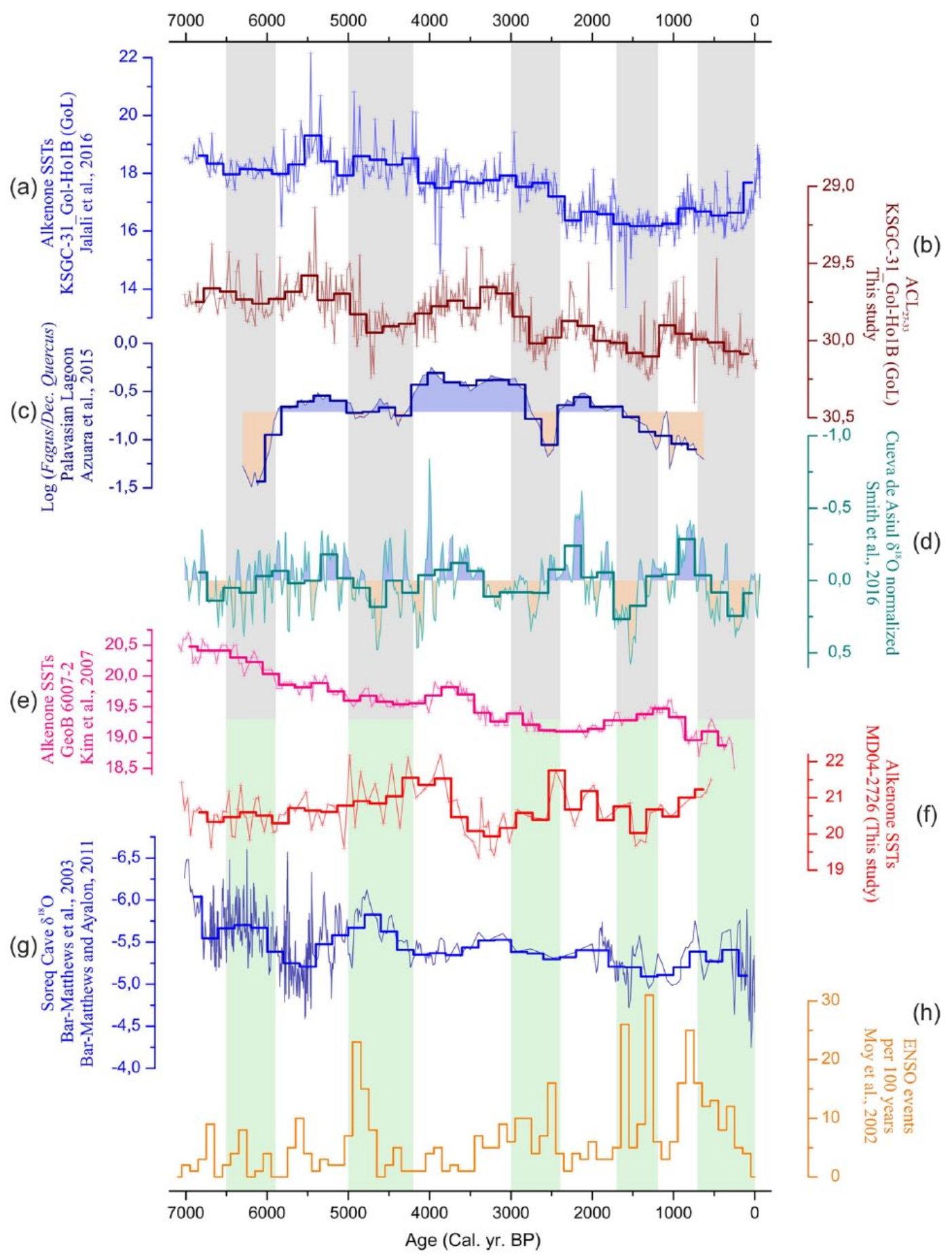

Figure 5. Reconstructions over the past 7000 years of (a) alkenone SSTs at the KSGC-3I_Gol-HolB site (from Jalali et al., 2016); (b) ACL $_{27-33}$ at KSGC-3I_Gol-HoIB core site (this study); (c) log Fagus/dec. Quercus ratios from Palavasian lagoon sediments obtained from Azuara et al. (2015) and complemented with new data from 4600 to $6500 \mathrm{yr}$ BP; (d) detrended $\delta^{18} \mathrm{O}$ data from the Cueva de Asiul stalagmite, Northern Spain (from Smith et al., 20I6); (e) alkenone SSTs at the GeoB 6007-2 site (from Kim et al., 2007); (f) alkenone SSTs in the MD04-2726 core (this study); (g) Soreq Cave speleothem $\delta^{18} \mathrm{O}$ record (from Bar-Matthews and Ayalon, 20I I; Bar-Matthews et al., 2003); and (h) number of ENSO events per 100 years (from Moy et al., 2002). A 200-year binning (darkened lines) was applied to all records to reduce the effect of error in the proxy reconstructions. Vertical shaded areas highlight dry spells in the NW Mediterranean.

time spans have also been inferred from forest pollen counts in Alboran Sea sediments (W Mediterranean) by Fletcher et al. (2012). Interestingly, these drier intervals in the W Mediterranean broadly match with wet intervals in the Eastern Mediterranean as, for example, those depicted by the depleted values in $\delta^{18} \mathrm{O}$ of the Soreq Cave record (Figure 5g), notably between 6500 and 4500 yr BP (Bar-Matthews and Ayalon, 2011). This is further supported by the lower $\delta^{13} \mathrm{C}$ data that closely follow the $\delta^{18} \mathrm{O}$ values indicating a well-developed soil cover favored by rainy conditions (not shown; Bar-Matthews and Ayalon, 2011). Finally, Migowski et al. (2006) reported coeval higher levels of the Dead Sea.
Potential mechanisms explaining this centennial-scale variability have been little explored, in part, because of the scarcity of high-resolution reconstructions. Instrumental data over the last decades have shown that higher winter precipitation in the Levant occurs during strong ENSO years (Price et al., 1998; Yakir et al., 1996). This link between rainfall and ENSO would involve a direct connection between the $\mathrm{E}$ Mediterranean and the indoPacific region through the meridional shift of the jet stream (Alpert et al., 2006). As can be seen from the Soreq stalagmite record (Figure $5 \mathrm{~g}$ ), wetter episodes in the Levant occur when El Niño events are more frequent (Figure 5h; Moy et al., 2002). According 
to Marriner et al. (2012), high Nile flows between 7000 and 4600 yr BP and during the Common Era would also be linked to increasing ENSO-like frequency. However, although both the Levant and Nile drainage catchment basin would have experienced enhanced humidity during strong ENSO, higher precipitation occurs in winter in the Levant region while in summer in the upper Nile drainage basin, that is, during the monsoon season.

Another possible mechanism to explain opposite climate signals between the eastern and western basins at centennial timescale has been proposed by Kushnir and Stein (2010). These authors found that higher precipitation in the Levant region occurred when SSTs in the tropical NE Atlantic are cold. They further showed using modeling experiments that colder than normal surface temperatures in the tropical NE Atlantic in winter promote a seesaw pattern of high pressures over NE Atlantic/W Mediterranean and low pressures in the eastern Mediterranean causing lower precipitations in W Mediterranean and higher ones in the Levant. Anticyclonic conditions over the NE Atlantic/W Mediterranean would divert the maritime westerly flow and associated moisture to the North leading to drier conditions in the $\mathrm{W}$ Mediterranean and Iberian Peninsula. In the GoL, this high-pressure system is associated with cold and dry continental local northerly winds, that is, Mistral and Tramontane, which blow over the NW Mediterranean and cause surface water cooling (Sicre et al., 2016). Mistral also prevents the inland penetration of maritime winds further contributing to drier conditions in southern France (Guenard et al., 2005). In the E Mediterranean, cyclogenesis and warmer SSTs favored higher than normal precipitation in the Levant region (Kushnir and Stein, 2010). Cold alkenone SSTs off NW Africa (GeoB 6007-2; Kim et al., 2007) and warm SSTs off SE Mediterranean (MD04-2726 and GeoB 7702-3) as, for example, between 5000 and $4200 \mathrm{yr}$ BP are consistent with this proposed large-scale atmospheric seesaw pattern (Figure 5e and f). Cold alkenone SSTs in the GoL and dryness in W Mediterranean and Iberian Peninsula, on one hand, and warm alkenone SSTs at the MD04-2726 site and wetter conditions in the Soreq cave, on the other hand, are also spatially coherent with the proposed mechanism.

\section{Conclusion}

High-resolution multi-proxy paleoclimate records from the Nile delta sediments were generated to document climate variability at regional scale and explore its link with subtropical climate over the past 10,000 years. SSTs off the Nile delta show strong fluctuations during the AHP and warming till $4200 \mathrm{yr}$ BP followed by two marked cooling at ca. 3500 and 1500 yr BP. Comparison between the Nile and Rhone delta (NW Mediterranean sea) reveals opposite SST temporal evolution that are consistent with the recent compilation of Mediterranean Holocene records of Jalali et al. (2016) and global synthesis of Marcott et al. (2013).

The variations in the Nile River discharge and environmental conditions in its drainage basin were reconstructed based on new records of TERR-alkanes, pollen, and $\mathrm{ACL}_{27-33}$ and already published Ti:Ca ratios. From this multi-proxy study of the Nile delta and comparison to the same proxy data from the GoL sediments, several conclusions can be drawn:

1. The Nile River runoff was highest between 10,000 and $8400 \mathrm{yr} \mathrm{BP}$ as indicated by higher TERR-alkanes, Ti:Ca ratios, and Pediastrum concentration values confirming previous findings of insolation-driven heavy monsoon rainfall associated with the latitudinal migration of the ITCZ.

2. A major dry episode was recognized in the Nile delta sediments at $\sim 9200$ yr BP suggesting reduced monsoon precipitation trigger by extratropical forcing. Our data also revealed the expansion of $\mathrm{C} 4$ grasses and savanna shrubs in the present-day Sahara between 8800 and $8400 \mathrm{yr}$ BP.

3. The early-Holocene Rhone River sediment supply indicated wetter conditions reflecting oceanic conditions and increase dryness as the Mediterranean climate established. However, non-climatic factors such as human-induced land cover changes (e.g. vegetation clearance) likely intensified erosion in particular during the past millennia.

4. Mid- to late-Holocene sub-millennial to centennial-scale variability in the Nile catchment basin and Levant region suggests a possible role of low-latitude teleconnection involving ENSO, mainly during periods of frequent ENSO. However, the mechanism proposed by Kushnir and Stein (2010) involving the tropical North Atlantic SSTs would account for the seesaw climate signals evidenced across the Mediterranean basin and notably enhanced precipitation in the Eastern Mediterranean and Levant region contrasting to drier conditions in the $\mathrm{W}$ Mediterranean and vice versa.

\section{Acknowledgements}

The authors thank MISTRALS/PaleoMex program for financial support and the crew for operating the MedifluxMIMES cruise and coring on the R/V Pelagia. They are also grateful to Nabil Sultan (IFREMER) and the crew operating the GMO2 Carnac cruise for providing facilities at sea. The crew of the N/V Néréis of the 'Observatoire Océanographique de Banuyls' (OOB) is acknowledged for allowing the recovering of the GolHo multi-core. Sfax Team acknowledges support from the 'French-Tunisian Joint Project PHC-Utique No. 14-G-1002'. They are also grateful to Marie Revel (Geoazur) for giving access to the sediment cores MS27PT and MD04-2726 and I. Bouloubassi for sample handling. M. Benrahmoune (LOCEAN) is also thanked for his participation in the biomarker analysis. Jean Pierre Cazet is thanked for processing pollen samples of the core MS27PT.

\section{Funding}

The author(s) received no financial support for the research, authorship, and/or publication of this article.

\section{References}

Alpert P, Baldi M, Ilani R et al. (2006) Relations between climate variability in the Mediterranean region and the tropics: ENSO, South Asian and African monsoons, hurricanes and Saharan dust. Developments in Earth and Environmental Sciences 4: 149-177.

Azuara J, Combourieu-Nebout N, Lebreton V et al. (2015) LateHolocene vegetation changes in relation with climate fluctuations and human activity in Languedoc (southern France). Climate of the past 11: 1769-1784.

Bar-Matthews M and Ayalon A (2011) Mid-Holocene climate variations revealed by high-resolution speleothem records from Soreq Cave, Israel and their correlation with cultural changes. The Holocene 21: 163-171.

Bar-Matthews M, Ayalon A, Gilmour M et al. (2003) Sea-land isotopic relationships from planktonic foraminifera and speleothems in the eastern Mediterranean region and their implications for paleorainfall during interglacial intervals. Geochimica et Cosmochimica Acta 67: 3181-3199.

Bassetti MA, Berné S, Sicre MA et al. (2016) Holocene hydrological changes of the Rhone River (NW Mediterranean) as recorded in the marine mud belt. Climate of the past 12: $1539-1553$.

Berger A and Loutre MF (1991) Insolation values for the climate of the last 10 million years. Quaternary Science Reviews 10: 297-317.

Blanchet CL, Contoux C and Leduc G (2015) Runoff and precipitation dynamics in the Blue and White Nile catchments 
during the mid-Holocene: A data-model comparison. Quaternary Science Reviews 130: 222-230.

Blanchet CL, Frank M and Schouten S (2014) Asynchronous changes in vegetation, runoff and erosion in the Nile River watershed during the Holocene. PLOS ONE 9(12): e115958. Available at: http://dx.doi.org/10.1371/journal.pone.0115958.

Blanchet CL, Tjallingii R, Frank M et al. (2013) High- and lowlatitude forcing of the Nile River regime during the Holocene inferred from laminated sediments of the Nile deep-sea fan. Earth and Planetary Science Letters 364: 98-110.

Castañeda IS, Schefuß E, Pätzold J et al. (2010) Millennial-scale sea surface temperature changes in the eastern Mediterranean (Nile River Delta region) over the last 27000 years. Paleoceanography 25: PA1208.

Cattaneo A and Steel RJ (2003) Transgressive deposits: A review of their variability. Earth-Science Reviews 62: 187-228.

Combourieu-Nebout N, Londeix L, Baudin F et al. (1999) Quaternary marine and continental paleoenvironments in the western Mediterranean (Site 976, Alboran Sea): Palynological evidence. In: Zahn R, Comas MC and Klaus A (eds) Proceedings of ODP Scientific Results, vol. 161. College Station, TX: Ocean Drilling Program, pp. 457-468.

Conte MH, Sicre MA, Rühlemann C et al. (2006) Global temperature calibration of the alkenone unsaturation index $\left(\mathrm{UK}_{37}\right)$ in surface waters and comparison with surface sediments. Geochemistry, Geophysics, Geosystems 7: Q02005.

Costa K, Russell J, Konecky B et al. (2014) Isotopic reconstruction of the African Humid Period and Congo air boundary migration at Lake Tana, Ethiopia. Quaternary Science Reviews 60: 368-376.

Delhon C and Thiébault S (2005) The migration of beech (Fagus sylvatica L.) up the Rhone: The Mediterranean history of a 'mountain' species. Vegetation History and Archaeobotany 1: $119-132$.

Faegri K and Iversen J (1989) Textbook of Pollen Analysis (ed K Faegri, PE Kaland and K Krzywinski). 4th Edition. Chichester: Wiley.

Fanget AS, Berné S, Jouet G et al. (2014) Impact of relative sea level and rapid climate changes on the architecture and lithofacies of the Holocene Rhone subaqueous delta (Western Mediterranean Sea). Sedimentary Geology 305: 35-53.

Fleitmann D, Burns SJ, Mangini A et al. (2007) Holocene ITCZ and Indian monsoon dynamics recorded in stalagmites from Oman and Yemen (Socotra). Quaternary Science Reviews 26: $170-188$

Fleitmann D, Mudelsee M, Burns SJ et al. (2008) Evidence for a widespread climatic anomaly at around 9.2 ka before present. Paleoceanography 23: PA1102.

Fletcher WJ, Debret M and Sanchez Goñi MF (2012) Mid-Holocene emergence of a low-frequency millennial oscillation in western Mediterranean climate: Implications for past dynamics of the North Atlantic atmospheric westerlies. The Holocene 23: 153-166.

Gagosian RB and Peltzer ET (1986) The importance of atmospheric input of terrestrial organic material to deep-sea sediments. Organic Geochemistry 10: 661-669.

Guenard V, Drobinski P, Caccia J et al. (2005) An observational study of the mesoscale mistral dynamics. Boundary-Layer Meteorology 115: 263-288.

Haug GH, Hughen KA, Sigman DM et al. (2001) Southward migration of the intertropical convergence zone through the Holocene. Science 293: 1304-1308.

Jalali B, Sicre MA, Bassetti MA et al. (2016) Holocene climate variability in the North-Western Mediterranean Sea (Gulf of Lions). Climate of the past 12: 91-101.

Jalut G, Dedoubat JJ, Fontugne M et al. (2009) Holocene circum-Mediterranean vegetation changes: Climate forcing and human impact. Quaternary International 200: 4-18.
Jalut G, Esteban Amat A, Bonnet L et al. (2000) Holocene climatic changes in the Western Mediterranean, from south-east France to south-east Spain. Palaeogeography, Palaeoclimatology, Palaeoecology 160: 255-290.

Jalut G, Esteban Amat A, Riera i Mora S et al. (1997) Holocene climatic changes in the western Mediterranean: Installation of the Mediterranean climate. Comptes Rendus de l'Academie des Sciences, Series IIA: Earth and Planetary Science 325: 327-334.

Jiménez-Espejo FJ, García-Alix A, Jiménez-Moreno G et al. (2014) Saharan aeolian input and effective humidity variations over western Europe during the Holocene from a high altitude record. Chemical Geology 374: 1-12.

Jiménez-Moreno G, Rodríguez-Ramírez A, Pérez-Asensio JN et al. (2015) Impact of late-Holocene aridification trend, climate variability and geodynamic control on the environment from a coastal area in SW Spain. The Holocene. Epub ahead of print 6 January. DOI: 10.1177/0959683614565955.

Joannin S, Ali AA, Ollivier V et al. (2014) Vegetation, fire and climate history of the Lesser Caucasus: A new Holocene record from Zarishat fen (Armenia). Journal of Quaternary Science 29: 70-82.

Kallel N, Duplessy JC, Labeyrie L et al. (2004) Mediterranean Sea palaeohydrology and pluvial periods during the Late Quaternary. In: Battarbee RW, Gasse F and Stickley CE (eds) Past Climate Variability through Europe and Africa. Dordrecht: Kluwer Academic, pp. 307-324.

Kallel N, Paterne M, Duplessy JC et al. (1997a) Enhanced rainfall in the Mediterranean region during the last sapropel event. Oceanologica Acta 20: 697-712.

Kallel N, Paterne M, Labeyrie L et al. (1997b) Temperature and salinity records of the Tyrrhenian Sea during the last 18,000 years. Palaeogeography, Palaeoclimatology, Palaeoecology 135: 97-108.

Kim JH, Meggers H, Rimbu N et al. (2007) Impact of the North Atlantic gyre circulation on Holocene climate off Northwest Africa. Geology 35: 387-390.

Kushnir Y and Stein M (2010) North Atlantic influence on 19th20th century rainfall in the Dead Sea watershed, teleconnections with the Sahel, and implication for Holocene climate fluctuations. Quaternary Science Reviews 29: 3843-3860.

Locarnini RA, Mishonov AV, Antonov JI et al. (2013) World Ocean Atlas 2013, Volume 1: Temperature. ed S Levitus; technical ed A Mishonov; NOAA Atlas NESDIS 73, 40 pp. Available at: http://www.nodc.noaa.gov/OC5/indprod.html.

Ludwig W, Dumont E, Meybeck M et al. (2009) River discharges of water and nutrients to the Mediterranean Sea: Major drivers for ecosystem changes during past and future decades? Progress in Oceanography 80: 199-217.

McGlynn G, Mooney S and Taylor D (2013) Palaeoecological evidence for Holocene environmental change from the Virunga, volcanoes in the Albertine Rift, central Africa. Quaternary Science Reviews 61: 32-46.

McGregor HV, Evans MN, Goosse H et al. (2015) Robust global ocean cooling trend for the pre-industrial Common Era. Nature Geoscience. Epub ahead of print 17 August. DOI: 10.1038/ngeo2510.

Magny M, Bossuet G, Ruffaldi P et al. (2011) Orbital imprint on Holocene palaeohydrological variations in west-central Europe as reflected by lake-level changes at Cerin (Jura Mountains, eastern France). Journal of Quaternary Science 26: $171-177$.

Magny M, Combourieu-Nebout N, de Beaulieu JL et al. (2013) North-south palaeohydrological contrasts in the central Mediterranean during the Holocene: Tentative synthesis and working hypotheses. Climate of the past 9: 2043-2071.

Magny M, de Beaulieu JL, Drescher-Schneider R et al. (2007) Holocene climate changes in the central Mediterranean as 
recorded by lake-level fluctuations at Lake Accesa (Tuscany, Italy). Quaternary Science Reviews 26: 1736-1758.

Marcott SA, Shakun JD, Clark PU et al. (2013) A reconstruction of regional and global temperature for the past 11300 years. Science 339: 1198-1201.

Marriner N, Flaux C, Kaniewski D et al. (2012) ITCZ and ENSOlike pacing of Nile delta hydro-geomorphology during the Holocene. Quaternary Science Reviews 45: 73-84.

Marshall MH, Lamb HF, Huws D et al. (2011) Late Pleistocene and Holocene drought events at Lake Tana, the source of the Blue Nile. Global and Planetary Change 78: 147-161.

Maselli V and Trincardi F (2013) Man made deltas. Scientific Reports. Available at: http://dx.doi.org/10.1038/srep01926.

Matthiessen J, Kunz-Pirrung M and Mudie P (2000) Freshwater chloro-phycean algae in recent marine sediments of the Beaufort, Laptev and Kara Seas (Arctic Ocean) as indicators of river runoff. International Journal of Earth Sciences 89: 470-485.

Melki T, Kallel N, Jorissen FJ et al. (2009) Abrupt climate change, sea surface salinity and paleoproductivity in the western Mediterranean Sea (Gulf of Lion) during the last $28 \mathrm{kyr}$. Palaeogeography, Palaeoclimatology, Palaeoecology. Epub ahead of print 18 May. DOI: 10.1016/j.palaeo.2009.05.005.

Migowski C, Mordechai S, Prasad S et al. (2006) Holocene climate variability and cultural evolution in the Near East from the Dead Sea sedimentary record. Quaternary Research 66: 421-431.

Moy CM, Seltzer GO, Rodbell DT et al. (2002) Variability of El Niño southern oscillation activity at millennial timescales during the Holocene epoch. Nature 420: 162-165.

Nittrouer CA, Kuehl SA, DeMaster DJ et al. (1986) The deltaic nature of Amazon shelf sedimentation. The Geological Society of America Bulletin 97: 444-458.

Olsen J, Anderson NJ and Knudsen MF (2012) Variability of the North Atlantic Oscillation over the past 5200 years. Nature Geoscience 5: 808-812.

Pérez-Obiol R, Jalut G, Julià R et al. (2011) Mid-Holocene vegetation and climatic history of the Iberian Peninsula. The Holocene 21: 75-93.

Pratson LF, Nittrouer CA, Wilberg P et al. (2007) Seascape evolution on clastic continental shelves and slopes. In: Nittrouer CA, Austin JA, Field ME et al. (eds) Continental Margin Sedimentation. Malden, MA: Blackwell (International Association of Sedimentologists Special Publication), pp. 339-381.

Price C, Stone L, Huppert A et al. (1998) A possible link between El Nino and precipitation in Israel. Geophysical Research Letters 25: 3963-3966.

Provansal M, Vella C, Arnaud-Fassetta G et al. (2003) Role of fluvial sediment inputs in the mobility of the Rhône delta coast (France). Geomorphologie Relief, Processus, Environnement 4: 271-282.

Quezel P (1979) La région méditerranéenne française et ses essences forestières, signification écologique dans le contexte circum-méditerranéen. Forêt Méditerranéenne 1: 7-18.

Revel M, Ducassou E, Skonieczny C et al. (2015) 20,000 years of Nile River dynamics and environmental changes in the Nile catchment area as inferred from Nile upper continental slope sediments. Quaternary Science Reviews 130: 200-221.

Roberts N, Eastwood WJ, Kuzucuoğlu C et al. (2011) Climatic, vegetation and cultural change in the eastern Mediterranean during the mid-Holocene environmental transition. The Holocene 21: 147-162.

Roberts N, Jones MD, Benkaddour A et al. (2008) Stable isotope records of Late Quaternary climate and hydrology from Mediterranean lakes: The ISOMED synthesis. Quaternary Science Reviews 27: 2426-2441.
Roberts N, Moreno A, Valero-Garces BL et al. (2012) Palaeolimnological evidence for an east-west climate see-saw in the Mediterranean since AD 900. Global and Planetary Change 84-85: 23-34.

Rohling EJ (1994) Review and new aspects concerning the formation of Mediterranean sapropels. Marine Geology 122: 1-28.

Rossignol-Strick M, Nesteroff W, Olive P et al. (1982) After the deluge: Mediterranean stagnation and sapropel formation. Nature 295: 105-110.

Rucina SM, Muiruri VM, Rahab N et al. (2009) Late Quaternary vegetation and fire dynamics on Mount Kenya. Palaeogeography, Palaeoclimatology, Palaeoecology 283: 1-14.

Sabatier P, Dezileau L, Colin C et al. (2012) 7000 years of paleostorm activity in the NW Mediterranean Sea in response to Holocene climate events. Quaternary Research 77: 1-11.

Schwark L, Zink K and Lechterbeck J (2002) Reconstruction of postglacial to early Holocene vegetation history in terrestrial Central Europe via cuticular lipid biomarkers and pollen records from lake sediments. Geology 30: 463-466.

Sicre MA and Peltzer ET (2004) Lipid geochemistry of remote aerosols from the southwestern Pacific Ocean sector. Atmospheric Environment 38: 1615-1624.

Sicre MA, Jalali B, Martrat B et al. (2016) Sea surface temperature variability in the North Western Mediterranean Sea (Gulf of Lions) during the Common Era. Earth and Planetary Science Letters. Epub ahead of print 12 October. DOI: 10.1016/j. tifl.2016.09.032.

Smith AC, Wynn PM, Barker PA et al. (2016) North Atlantic forcing of moisture delivery to Europe throughout the Holocene. Nature. Epub ahead of print 25 April. DOI: 10.1038/ srep24745.

Stockmarr J (1971) Tablets with spores used in absolute pollen analysis. Pollen et Spores 13: 615-621.

Ternois Y, Sicre MA and Paterne M (2000) Climatic changes along the northwestern African continental margin over the last 30 kyrs. Geophysical Research Letters 27: 133-136.

Trigo IF and Davies TD (2000) Decline in Mediterranean rainfall caused by weakening of Mediterranean cyclones. Geophysical Research Letters 27: 2913-2916.

Vijverberg J, Sibbing FA and Dejen E (2009) Lake Tana: Source of the Blue Nile. In: Dumont HJ (ed.) The Nile: Origin, Environments, Limnology, and Human Use, vol. 89. Dordrecht: Springer, pp. 163-192.

Vinther BM, Buchardt SL, Steffensen JP et al. (2006) A synchronized dating of three Greenland ice cores throughout the Holocene. Journal of Geophysical Research: Atmospheres 111: D06102.

Vogts A, Moossen H, Rommerskirchen F et al. (2009) Distribution patterns and stable carbon isotopic composition of alkanes and alkan-1-ols from plant waxes of African rain forest and savanna $\mathrm{C}_{3}$ species. Organic Geochemistry 40: 1037-1054.

Williams MAJ, Adamson D, Cock B et al. (2000) Late Quaternary environments in the White Nile region, Sudan. Global and Planetary Change 26: 305-316.

Yakir D, Lev-Yadun S and Zangvil A (1996) El Nino and tree growth near Jerusalem over the last 20 years. Global Change Biology 2: 101-105.

Zazo C, Mercier N, Silva PG et al. (2005) Landscape evolution and geodynamic controls in the Gulf of Cadiz (Huelva coast, SW Spain) during the Late Quaternary. Geomorphology 68: 269-290.

Ziveri P, Rutten A, de Lange G et al. (2000) Present-day coccolith fluxes recorded in central Eastern Mediterranean sediment traps and surface sediments. Palaeogeography, Palaeoclimatology, Palaeoecology 158: 175-195. 